\title{
Antioxidant and Angiotensin I Converting Enzyme Inhibitory Activities of Red Snow Crab Chionoecetes japonicas Shell Hydrolysate by Enzymatic Hydrolysis
}

\author{
Na Young Yoon*, Kil-Bo Shim, Chi-Won Lim and Sang-Bo Kim \\ Food and Safety Research Division, National Fisheries Research and Development Institute, Busan 617-705, Korea
}

\begin{abstract}
We investigated the antioxidant and angiotensin I converting enzyme (ACE) inhibitory activities of red snow crab Chionoecetes japonicas shell (RSCS) hydrolysate by enzymatic hydrolysis and its molecular weight cut-off fractions. The RSCS hydrolysate was fractionated through two ultrafiltration membranes of 3 and $10 \mathrm{kDa}$ cut-offs. Three fractions $(<3 \mathrm{kDa}, 3-10 \mathrm{kDa}$, and $>10 \mathrm{kDa})$ were evaluated for total amino acid composition, antioxidant activities using 2 '-azino-bis[3-ethylbenzthiazoline-6-sulfonic acid] $\left(\mathrm{ABTS}^{+}\right.$) radical scavenging and superoxide dismutase (SOD)-like activities and reducing power assays, and ACE inhibitory activity using Hou's method. Although all fractions showed activity, the $<3 \mathrm{kDa}$ fraction of RSCS hydrolysate exhibited the greatest $\mathrm{ABTS}^{+}$radical scavenging, SOD-like and ACE inhibitory activities. However, these fractions exhibited low reducing power. These results suggest that the low-molecular-weight enzymatic hydrolysate of RSCS could be used as a functional ingredient to control oxidative stress and ACE activity.
\end{abstract}

Key words: Chionoecetes japonicas, Antioxidant activity, Ansiotensin I converting enzyme, Hydrolysate, Red snow crab shell

\section{Introduction}

Blood pressure is regulated by various controlling factors including angiotensin I converting enzyme (ACE, EC 3.4.15.1). This enzyme is a bivalent dipeptidyl carboxyl metallopeptidase, which converts angiotensin I, an inactive decapeptide produced from angiotensinogen, into angiotensin II, a vasoconstrictive octapepide, and inactivates the vasodilator bradykinin, thus interacting simultaneously with the reninangiotensin and kallinkrein-kinin systems (Mäkinen et al., 2012). ACE inhibitors are one of the most effective methods for suppressing increases in blood pressure and have a long history of use, with interest in them continuing to increase (Pfeffer and Frohlich, 2006).

Oxidative stress occurs due to an imbalance between oxidizing species and natural antioxidants or antioxidant enzymes, and has been implicated in the occurrence of hypertension and a number of pathological conditions, including neurodegenerative diseases, diabetes, cancer, and aging (Beckman and Ames, 1998; Giasson et al., 2002). Reactive oxygen species (ROS), such as the superoxide anion radical $\left(\mathrm{O}_{2}^{-}\right)$, hydrogen peroxide, and hydroxyl radicals $(\cdot \mathrm{OH})$ are generated from the sequential reduction of oxygen during respiration in aerobic organisms. ROS are highly unstable, and react rapidly with other substances, including DNA, membrane lipids and proteins, and may cause cellular damage leading to apoptosis, aging, and inflammation (Je et al., 2009). Although the body has its own defense system against ROS, it cannot prevent oxidative damage completely. Thus, food supplements containing antioxidants can be used to reduce oxidative damage.

Red snow crab Chionoecetes japonicas, one of the most popular crab in Korea, is distributed widely in the deep-sea
http://dx.doi.org/10.5657/FAS.2013.0237

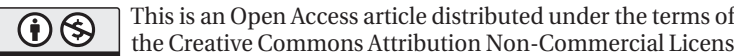
(http://creativecommons.org/licenses/by-nc/3.0/) which permits unrestricted non-commercial use, distribution, and reproduction in any medium, provided the original work is properly cited.
Received 04 September 2013; Revised 11 October 2013

Accepted 18 October 2013

*Corresponding Author

E-mail: dbssud@korea.kr 
at depths of $200-2,300 \mathrm{~m}$ in the waters around Korea and Japan (Lee et al., 1986). Crab processing by-products in the form of shells, heads, and feet account for as much as $80 \%$ of the total weight of the catch and comprise valuable and useful components, such as proteins, lipids, and chitin (Shahidi, 1994). Many researchers are interested in the utilization of protein-rich marine processing waste as nutraceuticals or nutritional supplements due to their good nutritional properties and a wide range of essential amino acids (Chae et al., 1998; Guerard et al., 2001; Arvanitoyannis and Kassaveti, 2008).

The aim of this study was to determine the effect on antioxidant and ACE activities of fractions of red snow crab shell (RSCS) hydrolysate of various molecular weights.

\section{Materials and Methods}

\section{Materials}

RSCS was purchased from a red snow crab processing plant (Sokcho, Korea) in July 2012. The lyophilized shell powder was stored in a freezer at $-20^{\circ} \mathrm{C}$ until use. 2,2-azino-bis (3-ethylbenzthiaxoline)-6-sulfonic acid $\left(\mathrm{ABTS}^{+}\right), o-$ phthaldialdehyde, pyrogallol, potassium persulfate, trolox, potassium ferricyanide, trichloroacetic acid, ferric chloride, angiotensin I converting enzyme, N-[3-(2-furyl) acryloyl]Phe-Gly-Gly (FAPGG), captopril, and L-ascorbic acid were purchased from Sigma Chemical Co. (St. Louis, MO, USA) and Alcalase $2.4 \mathrm{~L}$ was purchased from Novo Co. (Novozyme Laboratories, Copenhagen, Denmark). All other reagents were of the highest grade available.

\section{Enzymatic hydrolysis and fractionation}

RSCS was used for enzymatic hydrolysis. Its crude protein content was $27.37 \%$ as determined by the Kjeldahl method. Alcalase $2.4 \mathrm{~L}$ was used to prepare RSCS protein hydrolysate under optimal conditions $\left(50^{\circ} \mathrm{C}, \mathrm{pH} 7.0\right)$. A sample $(100$ g) and enzyme $(0.27 \mathrm{~g})$ were mixed and hydrolyzed at $50^{\circ} \mathrm{C}$ for $25 \mathrm{~h}$. After $25 \mathrm{~h}$, the mixture was heated at $100^{\circ} \mathrm{C}$ to inactivate the enzyme. Unhydrolyzed proteins were removed by passing the hydrolysate through filter paper, and the supernatant was lyophilized $(13.70 \mathrm{~g})$ and stored at $-20^{\circ} \mathrm{C}$ until use.

The lyophilized hydrolysate $(12.70 \mathrm{~g})$ was dissolved in deionized water at $50 \mathrm{mg} / \mathrm{mL}$. The solution was filtered by two ultrafiltration membranes (Amicon Ultra-4 filter devices; Millipore, Billerica, MA, USA) with 3 and $10 \mathrm{kDa}$ molecular weight cut-offs (MWCO), yielding three fractions corresponding to molecular weights $<3 \mathrm{kDa}(5.80 \mathrm{~g}), 3-10 \mathrm{kDa}$ (4.72 g), and $>10 \mathrm{kDa}(2.18 \mathrm{~g})$. The soluble fractions were prepared by centrifuging at 3,000 rpm for $20 \mathrm{~min}$ and were passed through the membranes sequentially, beginning with the largest MWCO membrane cartridge $(10 \mathrm{kDa})$. The retentate and permeate were collected separately, and the retentate was recirculated into the feed until the maximum permeate yield was reached. Permeate from the $10 \mathrm{kDa}$ membrane was then filtered through the $3 \mathrm{kDa}$ membrane with recirculation until the maximum permeate yield was reached.

\section{Degree of hydrolysis (DH)}

The DH was calculated by determining free amino groups with o-phthaldialdehyde (Nielsen, 1999).

$$
\mathrm{DH}=\mathrm{h} / \mathrm{h}_{\mathrm{tot}} \times 100
$$

, where $h_{\text {tot }}$ is the total number of peptide bonds per protein equivalent, and $h$ is the number of hydrolyzed bonds. The $h_{\text {tot }}$ factor is dependent on the amino acid composition of the raw material.

\section{Total amino acids}

The total amino acid composition was determined using an amino acid analyzer (S43000; Sykam, Eresing, Germany). Samples were hydrolyzed in $6 \mathrm{~N}$ hydrochloric acid in vacuum-sealed tubes at $110^{\circ} \mathrm{C}$ for $24 \mathrm{~h}$.

\section{$\mathrm{ABTS}^{+}$radical scavenging activity}

$\mathrm{ABTS}^{+}$radical scavenging activity was determined by modifying the method of Arnao et al. (2001). The stock solutions were $7.4 \mathrm{mM} \mathrm{ABTS}^{+}$and $2.6 \mathrm{mM}$ potassium persulfate. The working solution was prepared by mixing the two stock solutions in equal quantities. The mixture was allowed to react for $12 \mathrm{~h}$ at room temperature in the dark, followed by dilution by mixing $1 \mathrm{~mL} \mathrm{ABTS}^{+}$solution with $50 \mathrm{~mL} \mathrm{MeOH}$ to an absorbance at $734 \mathrm{~nm}$ of $1.10 \pm 0.02$, as determined using a spectrophotometer (BioMate 5; Thermo Electron, Waltham, MA, USA). Fresh $\mathrm{ABTS}^{+}$solution was prepared for each assay. A sample $(150 \mu \mathrm{L})$ was mixed with $2.85 \mathrm{~mL} \mathrm{ABTS}^{+}$solution and the mixture was left in the dark for $2 \mathrm{~h}$. The absorbance at 734 nm was then measured using a spectrophotometer. Trolox was used as a positive control. $\mathrm{ABTS}^{+}$radical scavenging activity was calculated using the following equation:

$$
\text { Scavenging activity }(\%)=[1-\{(\mathrm{A}-\mathrm{B}) / \mathrm{C}\}] \times 100
$$

where, $\mathrm{A}=$ Absorbance of sample/Standard with reagent, $\mathrm{B}=$ Absorbance of sample/Standard without reagent, and $\mathrm{C}=$ Absorbance of the control.

\section{Superoxide dismutase (SOD)-like activity}

The SOD-like activity of RSCS hydrolysate was determined using the method described by Marklund and Marklund (1974) with a slight modification. Briefly, $200 \mu \mathrm{L}$ of sample solutions were mixed with $200 \mu \mathrm{L}$ of pyrogallol solution (7.2 $\mathrm{mM}$ in water) and $3 \mathrm{~mL}$ of $50 \mathrm{mM}$ Tris- $\mathrm{HCl}$ buffer, at $\mathrm{pH} 8.5$, containing $10 \mathrm{mM}$ EDTA. After $10 \mathrm{~min}, 1 \mathrm{~mL}$ of $1 \mathrm{~N} \mathrm{HCl}$ was 
added to the above mixture to stop the reaction. L-ascorbic acid was used as a positive control. The absorbance was measured at $420 \mathrm{~nm}$. SOD-like activity was calculated using the following equation:

$$
\text { Scavenging activity }(\%)=[1-\{(\mathrm{A}-\mathrm{B}) / \mathrm{C}\}] \times 100
$$

where, $\mathrm{A}=$ Absorbance of sample/Standard with reagent, $\mathrm{B}=$ Absorbance of sample/Standard without reagent, and $\mathrm{C}=$ Absorbance of the control.

\section{Reducing power}

Reducing power was evaluated by the method of Oyaizu (1986). Various sample concentrations $(2.5 \mathrm{~mL})$ were mixed with $2.5 \mathrm{~mL}$ of $200 \mathrm{mM}$ sodium phosphate buffer ( $\mathrm{pH}$ 6.6) and $2.5 \mathrm{~mL}$ of $1 \%$ potassium ferricyanide. After incubation at $50^{\circ} \mathrm{C}$ for $20 \mathrm{~min}, 2.5 \mathrm{~mL}$ of $10 \%$ trichloroacetic acid (w/v) were added. The mixture was then centrifuged at 2,000 $\mathrm{g}$ for $10 \mathrm{~min}$, and $5 \mathrm{~mL}$ of the upper layer were mixed with deionized water and $1 \mathrm{~mL}$ of $0.1 \%$ ferric chloride. The sample concentration resulting in 0.5 of absorbance $\left(\mathrm{EC}_{50}\right)$ was calculated from the graph of absorbance at $700 \mathrm{~nm}$, which was measured using a spectrophotometer (BioMate 5). L-ascorbic acid was used as a positive control.

\section{ACE inhibitory activity}

The inhibition of ACE activity was conducted according to the method of Hou et al. (2003), and modified to use FAPGG as the substrate. In brief, FAPGG $(0.5 \mathrm{mM})$ and various concentrations of the samples were completely dissolved in $50 \mathrm{mM}$ Tris- $\mathrm{HCl}$ buffer (pH 7.5). $20 \mu \mathrm{L}$ of ACE (1 U/mL dissolved in $50 \mathrm{mM}$ Tris-HCl buffer) were then mixed with $200 \mu \mathrm{L}$ of samples of various concentrations as experimental samples, or mixed with $50 \mathrm{mM}$ Tris- $\mathrm{HCl}$ buffer as a negative control. Following the addition of $1 \mathrm{~mL}$ of $0.5 \mathrm{mM}$ FAPGG to the reaction mixture, the optical density was determined after 0 and $30 \mathrm{~min}$ at a wavelength of $345 \mathrm{~nm}$. The ACE inhibitory activities were expressed as the $50 \%$ inhibition concentration $\left(\mathrm{IC}_{50}\right)$. The values of percentage inhibition were then calculated using the equation:

Inhibitory activity $(\%)=\left\{1-\left(\mathrm{OD}_{\text {sample/ } 0 \text { min }}-\mathrm{OD}_{\text {sample/30min }}\right) /\right.$

$$
\left.\left(\mathrm{OD}_{\text {control } / 0 \min }-\mathrm{OD}_{\text {control } / 30 \mathrm{~min}}\right)\right\} \times 100 \text {. }
$$

The antihypertensive agent captopril was used as a positive control.

\section{Statistical analysis}

The data were analyzed using analysis of variance through the general linear model procedure (SAS Institute, Cary, NC, USA). Duncan's multiple-range test was applied to determine the significance of differences between means $(P<0.05)$.

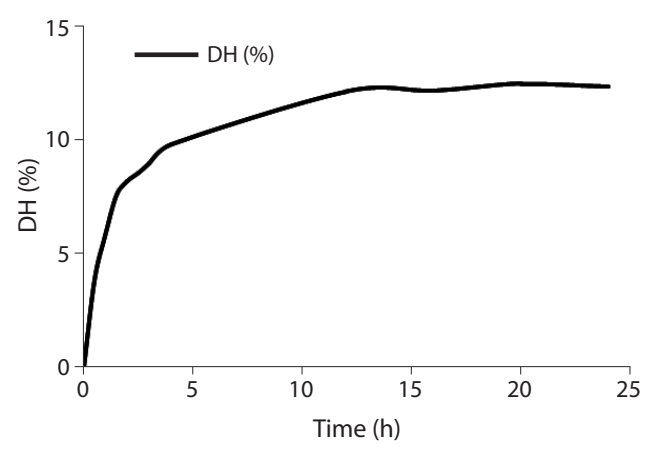

Fig. 1. The degree of hydrolysis $(\mathrm{DH})$ of red snow crab shell hydrolysate by Alcalase.

\section{Results and Discussion}

\section{Enzymatic hydrolysis and fractionation}

The bioactive protein hydrolysates depend on the protein substrate used, the specificity of the enzyme used, the conditions used during hydrolysis and the DH value (Nielsen, 1999; Kristinsson and Rasco, 2000). Because enzymes have specific cleavage positions on polypeptide chains, Alcalase has been used to produce bioactive peptides from processing by-products (Guerard et al., 2007).

The extent of protein degradation by proteolytic enzymes was estimated by assessing the DH. As shown in Fig. 1, the rate of enzymatic hydrolysis of RSCS increased rapidly for the first $2 \mathrm{~h}$ and then entered a steady-state phase after $12 \mathrm{~h}$ with a DH of $12.5 \%$. Alcalase hydrolysate was separated using two filters of MWCO 3 and $10 \mathrm{kDa}$ to yield three fractions $(<3$ $\mathrm{kDa}, 3-10 \mathrm{kDa}$, and $>10 \mathrm{kDa})$.

\section{Total amino acid composition}

The total amino acid compositions of RSCS hydrolysate and its fractions are presented in Table 1. The total amino acid content of RSCS hydrolysate was $72.48 \mathrm{~g} / 100 \mathrm{~g}$, which was the highest of any fraction (Table 1). However, the total amino acid compositions of RSCS hydrolysate and its three fractions were similar. All hydrolysate fractions were rich in Glu, Asp, Gly, and Ala, but contained low levels of Met and Cys.

The carboxyl ends of Glu, Met, Leu, Tyr, and Lys in the peptide linkages were found to be preferentially cleaved by Alcalase (Adamson and Reynolds, 1996). Of these, Glu was the major amino acid in RSCS hydrolysate, which made it a good substrate for Alcalase (Yang et al., 2011).

\section{Antioxidant activity}

Oxidative stress is a common risk factor in a number of chronic diseases, such as hypertension, diabetes, arthritis, neurodegenerative disease, and cardiovascular complications 
(Bernardini et al., 2011; Je et al., 2005). Excessive production of ROS causes adverse effects in cells, such as oxidation of bio-molecules. Therefore, ROS production must be regulated by antioxidants and antioxidant systems (Himaya et al., 2012).

The antioxidant activities of RSCS hydrolysate and its three MWCO fractions were evaluated to determine their $\mathrm{ABTS}^{+}$ radical scavenging activity, SOD-like activity, and reducing power (Table 2). The $<3 \mathrm{kDa}$ fraction exhibited the greatest antioxidant activity.

The scavenging activities of RSCS hydrolysate and its three fractions toward $\mathrm{ABTS}^{+}$radicals were as follows: $<3 \mathrm{kDa}$ fr. $\left(\mathrm{IC}_{50}=0.135 \pm 0.006 \mathrm{mg} / \mathrm{mL}\right)>3-10 \mathrm{kDa}$ fr. $\left(\mathrm{IC}_{50}=0.137 \pm\right.$ $0.001 \mathrm{mg} / \mathrm{mL})>$ RSCS hydrolysate $\left(\mathrm{IC}_{50}=0.190 \pm 0.011 \mathrm{mg} /\right.$

Table 1. Total amino acid composition of RSCS hydrolysate and its molecular weight cut-off fractions $(\mathrm{g} / 100 \mathrm{~g})$

\begin{tabular}{ccccc}
\hline $\begin{array}{c}\text { Amino } \\
\text { acids }\end{array}$ & $\begin{array}{c}\text { RSCS } \\
\text { hydrolysate }\end{array}$ & $<\mathbf{3 ~ k D a}$ & $\mathbf{3 - 1 0} \mathbf{~ k D a}$ & $>\mathbf{1 0}$ kDa \\
\hline Asp & 8.18 & 5.81 & 8.13 & 6.47 \\
Thr & 3.76 & 3.41 & 3.71 & 2.49 \\
Ser & 4.27 & 3.82 & 4.22 & 4.15 \\
Glu & 10.16 & 8.95 & 10.10 & 7.71 \\
Pro & 4.77 & 2.76 & 4.72 & 0.42 \\
Gly & 5.08 & 4.92 & 5.03 & 4.21 \\
Ala & 4.72 & 5.14 & 4.67 & 3.64 \\
Cys & 0.31 & 0.11 & 0.26 & 0.30 \\
Val & 4.13 & 3.80 & 4.08 & 2.45 \\
Met & 1.39 & 1.45 & 1.32 & 0.99 \\
Ile & 2.33 & 2.11 & 2.28 & 1.35 \\
Leu & 5.16 & 4.96 & 5.11 & 3.68 \\
Tyr & 2.75 & 2.66 & 2.70 & 2.19 \\
Phe & 3.27 & 3.29 & 3.22 & 2.47 \\
His & 2.28 & 1.88 & 2.23 & 3.46 \\
Lys & 5.18 & 4.09 & 5.13 & 3.88 \\
Arg & 5.57 & 4.42 & 5.52 & 4.44 \\
Total & 72.48 & 63.59 & 72.43 & 54.30 \\
\hline
\end{tabular}

RSCS, red snow crab shell.
$\mathrm{mL})>>10 \mathrm{kDa}$ fr. $\left(\mathrm{IC}_{50}=0.221 \pm 0.002 \mathrm{mg} / \mathrm{mL}\right)$ (Table 2). Thus the $<3 \mathrm{kDa}$ fraction was the most potent scavenger of $\mathrm{ABTS}^{+}$radicals. The $3-10 \mathrm{kDa}$ and $>10 \mathrm{kDa}$ fractions, and RSCS hydrolysate, also exhibited noticeable scavenging activity.

SOD is an antioxidative enzyme that catalyzes the breakdown of the superoxide anion into oxygen and hydrogen peroxide. This is a widely used assay to predict the SOD-like antioxidant activity, and is based inhibition of the auto-oxidation of pyrogallol. RSCS hydrolysate and the three MWCO fractions exhibited SOD-like activity with $\mathrm{IC}_{50}$ values of $1.602 \pm$ $0.128,1.180 \pm 0.037,1.580 \pm 0.118$, and $1.619 \pm 0.242 \mathrm{mg} /$ $\mathrm{mL}$, respectively (Table 2). Of these, the $<3 \mathrm{kDa}$ fraction showed the greatest SOD-like activity. However, all fractions exhibited lower SOD-like activity than the positive control, L-ascorbic acid.

Reducing power is the ability to reduce ferric $\left(\mathrm{Fe}^{3+}\right)$ to ferrous $\left(\mathrm{Fe}^{2+}\right)$, which can be a direct correlation between antioxidant activity and the reducing power of bioactive constituents (Dorman et al., 2003).

The RSCS hydrolysate and its three fractions had electron donation capacity (Table 2$)$. The $<3 \mathrm{kDa}$ fr. $\left(\mathrm{IC}_{50}=2.836 \pm\right.$ $0.242 \mathrm{mg} / \mathrm{mL}$ ) exhibited the greatest reducing power. However, all fractions showed lower reducing power than the positive control, L-ascorbic acid.

The differences in antioxidative activity among hydrolysates of different molecular weights might be due to their diverse amino acid compositions (Wu et al., 2003). Aromatic amino acids; i.e., Tyr, His and Phe (Chen et al., 1998; Rajapakse et al., 2005), and hydrophobic amino acids, comprising Val, Leu and Ala (Mendis et al., 2005), have been reported to play an important role in antioxidative activities.

\section{ACE inhibitory activity}

The ACE activation causes a rise of blood pressure by increasing vascular resistance and fluid volume, while ACE inhibitors exert an antihypertensive effect (Zhao and Li, 2009). Synthetic ACE inhibitors, including captopril, enalapril, alace-

Table 2. Antioxidant activities of RSCS hydrolysate and its molecular weight cut-off fractions

\begin{tabular}{lccc}
\hline Hydrolysate fractions & $\begin{array}{c}\text { ABTS }{ }^{+} \text {radical scavenging activity } \\
\left(\mathbf{I C}_{\mathbf{5 0}}{ }^{*}, \mathbf{m g} / \mathbf{m L}\right)\end{array}$ & $\begin{array}{c}\text { SOD-like activity } \\
\left(\mathbf{I C}_{\mathbf{5 0}}, \mathbf{m g} / \mathbf{m L}\right)\end{array}$ & $\begin{array}{c}\text { Reducing power } \\
\left.\mathbf{E C}_{\mathbf{5 0}}{ }^{*}, \mathbf{m g} / \mathbf{m L}\right)\end{array}$ \\
\hline RSCS hydrolysate & $0.190 \pm 0.011^{\mathrm{b}}$ & $1.602 \pm 0.128^{\mathrm{a}}$ & $5.629 \pm 0.067^{\mathrm{b}}$ \\
$<3 \mathrm{kDa}$ & $0.135 \pm 0.006^{\mathrm{c}}$ & $1.180 \pm 0.037^{\mathrm{b}}$ & $2.836 \pm 0.242^{\mathrm{c}}$ \\
$3-10 \mathrm{kDa}$ & $0.137 \pm 0.001^{\mathrm{c}}$ & $1.580 \pm 0.118^{\mathrm{a}}$ & $7.189 \pm 0.109^{\mathrm{a}}$ \\
$>10 \mathrm{kDa}$ & $0.221 \pm 0.002^{\mathrm{a}}$ & $1.619 \pm 0.242^{\mathrm{a}}$ & $7.964 \pm 0.266^{\mathrm{a}}$ \\
Trolox $^{\dagger}$ & $0.075 \pm 0.003^{\mathrm{d}}$ & & $0.009 \pm 0.0004^{\mathrm{d}}$ \\
L-ascorbic acid $^{\dagger}$ & & $0.038 \pm 0.008^{\mathrm{c}}$ & \\
\hline
\end{tabular}

RSCS, red snow crab shell; SOD, superoxide dismutase.

${ }^{*} \mathrm{I} \mathrm{C}_{50}$ and $\mathrm{EC}_{50}$ values of $\mathrm{ABTS}{ }^{+}$radical scavenging and SOD-like activities, and reducing power were expressed as mean \pm standard deviation (SD).

${ }^{+, \neq}$Trolox and L-ascorbic acid were used as positive controls of $\mathrm{ABTS}^{+}$radical scavenging, SOD-like activities and reducing power, respectively.

${ }^{a-d}$ Different letters indicated the statistical difference $(P<0.05)$. 
Table 3. ACE inhibitory activity of RSCS hydrolysate and its molecular weight cut-off fractions

\begin{tabular}{cc}
\hline Hydrolysate fractions & $\begin{array}{c}\text { ACE inhibitory activity } \\
\left(\mathbf{I C}_{50}{ }^{*}, \mathbf{m g} / \mathbf{m L}\right)\end{array}$ \\
\hline RSCS hydrolysate & $0.471 \pm 0.012^{\mathrm{b}}$ \\
$<3 \mathrm{kDa}$ & $0.307 \pm 0.018^{\mathrm{d}}$ \\
$3-10 \mathrm{kDa}$ & $0.423 \pm 0.011^{\mathrm{c}}$ \\
$>10 \mathrm{kDa}$ & $0.513 \pm 0.032^{\mathrm{a}}$ \\
Captopril $^{\dagger}(\mu \mathrm{g} / \mathrm{mL})$ & $0.004 \pm 0.0003^{\mathrm{e}}$ \\
\hline
\end{tabular}

$\mathrm{ACE}$, angiotensin I converting enzyme; RSCS, red snow crab shell.

${ }^{*} \mathrm{IC}_{50}$ values of ACE inhibitory activity was expressed as mean \pm standard deviation (SD).

${ }^{\dagger}$ Captopril was used as a positive control of ACE inhibitory activity.

${ }^{\text {a-e }}$ Different letters indicated the statistical difference $(P<0.05)$.

pril, fosinopril, and lisinopril, have been used for the treatment of hypertension and heart failure (Brown and Vaughan, 1998). However, these synthetic antihypertensive agents cause side effects such as coughing, taste alterations, skin rashes, and angioneurotic edema (Alderman, 1996; Cicoira et al., 2001; Vyssoulis et al., 2001). Therefore, much interest has focused on the use of safe ACE inhibitors derived from natural products to reduce side effects.

The ACE inhibitory activity of RSCS hydrolysate and its MWCO fractions is shown in Table 3 . The $<3 \mathrm{kDa}$ fraction exhibited the highest ACE inhibitory activity $\left(\mathrm{IC}_{50}=0.307\right.$ $\pm 0.018 \mathrm{mg} / \mathrm{mL}$ ), followed by the $3-10 \mathrm{kDa}$ fraction $\left(\mathrm{IC}_{50}=\right.$ $0.423 \pm 0.011 \mathrm{mg} / \mathrm{mL})$, RSCS hydrolysate $\left(\mathrm{IC}_{50}=0.471 \pm\right.$ $0.012 \mathrm{mg} / \mathrm{mL})$, and the $>10 \mathrm{kDa}$ fraction $\left(\mathrm{IC}_{50}=0.513 \pm 0.032\right.$ $\mathrm{mg} / \mathrm{mL}$ ). These results indicate that the order of the inhibition of ACE activity is similar to that for antioxidant activities.

In recent years, inhibition of ACE and antioxidant activity has been reported for bioactive peptides isolated from processing by-products such as Alaska pollock skin gelatin (Kim et al., 2001), yellow fin sole frame (Jung et al., 2006), big eye tuna dark muscle (Qian et al., 2007), tuna frame protein (Lee et al., 2010), Pacific cod skin gelatin (Himaya et al., 2012), hoki frame protein (Kim et al., 2007), Nile tilapia skin gelatin (Ngo et al., 2010), and tuna backbone protein (Je et al., 2005). Most of these active peptides were of low molecular weight, in the range 1-6 $\mathrm{kDa}$.

In conclusion, RSCS enzymatic hydrolysate and its MWCO fractions showed antioxidant activity and inhibited ACE activity. More detailed investigations are necessary to isolate and identify the active constituents of the hydrolysate and to determine the mechanism of action.

\section{Acknowledgements}

This research was funded by a grant from the National Fisheries Research and Development Institute, Korea (RP2013-FS-040).

\section{References}

Adamson NJ and Reynolds EC. 1996. Characterization of casein phosphopeptides prepared using alcalase: determination of enzyme specificity. Enzyme Microb Technol 19, 202-207. http://dx.doi. org/10.1016/0141-0229(95)00232-4.

Alderman CP. 1996. Adverse effects of the angiotensin-converting enzyme inhibitors. Ann Pharmacother 30, 55-61.

Arnao MB, Cano A and Acosta M. 2001. The hydrophilic and lipophilic contribution to total antioxidant activity. Food Chem 73, 239-244. http://dx.doi.org/10.1016/S0308-8146(00)00324-1.

Arvanitoyannis I and Kassaveti A. 2008. Fish industry waste: treatments, environmental impacts, current and potential uses. Int J Food Sci Technol 43, 726-745. http://dx.doi.org/10.1111/j.13652621.2006.01513.x.

Beckman KB and Ames BN. 1998. The free radical theory of aging matures. Physiol Rev 78, 547-581.

Bernardini RD, Harnedy P, Bolton D, Kerry J, O’Neill E, Mullen AM and Hayes M. 2011. Antioxidant and antimicrobial peptidic hydrolysates from muscle protein sources and by-products. Food Chem 124, 1296-1307. http://dx.doi.org/10.1016/j.foodchem.2010.07.004.

Brown NJ and Vaughan DE. 1998. Angiotensin-converting enzyme inhibitors. Circulation 97,1411-1420. http://dx.doi.org/10.1161/01. CIR.97.14.1411.

Chae HJ, In MJ and Kim MH. 1998. Process development for the enzymatic hydrolysis of food protein: effects of pre-treatment and post-treatments on degree of hydrolysis and other product characteristics. Biotechnol Bioprocess Eng 3, 35-39. http://dx.doi. org/10.1007/BF02932481.

Chen HM, Muramoto K, Yamauchi F, Fujimoto K and Nokihara K. 1998. Antioxidative properties of histidine-containing peptides designed from peptide fragments found in the digests of a soybean protein. J Agric Food Chem 46, 9-53. http://dx.doi.org/10.1021/ jf970649w.

Cicoira M, Zanolla L, Rossi A, Golia G, Franceschini L, Cabrini G, Bonizzato A, Graziani M, Anker SD, Coats AJS and Zardini P. 2001. Failure of aldosterone suppression despite angiotensin-converting enzyme (ACE) inhibitor administration in chronic heart failure is associated with ACE DD genotype. J Am Coll Cardiol 37, 18081812. http://dx.doi.org/10.1016/S0735-1097(01)01237-2.

Dorman HJD, Peltoketo A, Hiltunen R and Tikkanen MJ. 2003. Characterisation of the antioxidant properties of de-odourised aqueous extracts from selected Lamiaceae herbs. Food Chem 83, 255-262. http://dx.doi.org/10.1016/S0308-8146(03)00088-8.

Giasson BI, Ischiropoulos H, Lee VMY and Trojanowski JQ. 2002. The relationship between oxidative/nitrative stress and pathological inclusions in Alzheimer's and Parkinson's diseases. Free Radical Biol Med 32,1264-1275. http://dx.doi.org/10.1016/S08915849(02)00804-3.

Guérard F, Dufossé L, de la Broise D and Binet A. 2001. Enzymatic hydrolysis of proteins from yellowfin tuna (Thunnus albacares) wastes using alcalase. J Mol Catal B Enzym 11, 1051-1059. http:// dx.doi.org/10.1016/S1381-1177(00)00031-X. 
Guerard F, Sumaya-Martinez MT, Laroque D, Chabeaud A and Dufossé L. 2007. Optimization of free radical scavenging activity by response surface methodology in the hydrolysis of shrimp processing discards. Process Biochem 42, 1486-1491. http://dx.doi. org/10.1016/j.procbio.2007.07.016.

Himaya SWA, Ngo DH, Ryu BM and Kim SK. 2012. An active peptide purified from gastrointestinal enzyme hydrolysate of pacific cod skin gelatin attenuates angiotesin-I converting enzyme (ACE) activity and cellular oxidative stress. Food Chem 132, 1872-1882. http://dx.doi.org/10.1016/j.foodchem.2011.12.020.

Hou WC, Chen HJ and Lin YH. 2003. Antioxidant peptides with angiotensin converting enzyme inhibitory activities and applications for angiotensin converting enzyme purification. J Agric Food Chem 51, 1706 -1709. http://dx.doi.org/10.1021/jf0260242.

Je JY, Park PJ, Kim EK and Ahn CB. 2009. Antioxidant and angiotensin I converting enzyme inhibitory activity of Bambusae caulis in Liquamen. Food Chem 113, 932-935. http://dx.doi.org/10.1016/j. foodchem.2008.08.022

Je YJ, Park PJ and Kim SK. 2005. Antioxidant activity of a peptide isolated from Alaska pollack (Theragra chalcogramma) frame protein hydrolysate. Food Res Int 38, 45-50. http://dx.doi.org/10.1016/j. foodres.2004.07.005.

Jung WK, Mendis E, Je JY, Park PJ, Son BW, Kim HC, Choi YK and Kim SK. 2006. Angiotensin I-converting enzyme inhibitory peptide from yellowfin sole (Limanda aspera) frame protein and its antihypertensive effect in spontaneously hypertensive rats. Food Chem 94, 26-32. http://dx.doi.org/10.1016/j.foodchem.2004.09.048.

Kim SK, Kim YT, Byun HG, Nam KS, Joo DS and Shahidi F. 2001. Isolation and characterization of antioxidative peptides from gelatin hydrolysate of Alaska pollack skin. J Agric Food Chem 49, 19841989. http://dx.doi.org/10.1021/jf000494j.

Kim SY, Je JY and Kim SK. 2007. Purification and characterization of antioxidant peptide from hoki (Johnius belengerii) frame protein by gastrointestinal digestion. J Nutr Biochem 18, 31-38. http:// dx.doi.org/10.1016/j.jnutbio.2006.02.006.

Kristinsson HG and Rasco BA. 2000. Fish protein hydrolyates: production, biochemical and functional properties. Crit Rev Food Sci Nutr 40, 43-81. http://dx.doi.org/10.1080/10408690091189266.

Lee BG, Lee JH and Shim HI. 1986. Fishing experiment for development of unused Fishery resources on the deep sea bed of Kor East Sea. Bull Korean Fish Technol Soc 22, 61-70.

Lee SH, Qian ZJ and Kim SK. 2010. A novel angiotensin I converting enzyme inhibitory peptide from tuna frame protein hydrolysate and its antihypertensive effect in spontaneously hypertensive rats. Food Chem 118, 96-102. http://dx.doi.org/10.1016/j.foodchem.2009.04.086.

Mäkinen S, Johannson T, Gerd EV, Pihlava JM and Pihlanto A. 2012. Angiotensin I-converting enzyme inhibitory and antioxidant properties of rapeseed hydrolysates. J Funct Foods 4, 575-583. http:// dx.doi.org/10.1016/j.jff.2012.03.003.

Marklund S and Marklund G. 1974. Involvement of the superoxide anion radical in the autoxidation of pyrogallol and a convenient as- say for superoxide dismutase. Eur J Biochem 47, 469-474. http:// dx.doi.org/10.1111/j.1432-1033.1974.tb03714.x.

Mendis E, Rajapakse N, Byun HG and Kim SK. 2005. Investigation of jumbo squid (Dosidicus gigas) skin gelatin peptides for their in vitro antioxidant effects. Life Sci 77, 2166-2178. http://dx.doi. org/10.1016/j.lfs.2005.03.016.

Ngo DH, Qian ZJ, Ryu BM, Park JW and Kim SK. 2010. In vitro antioxidant activity of a peptide isolated from Nile tilapia (Oreochromis niloticus) scale gelatin in free radical-mediated oxidative systems. J Funct Foods 2, 107-117. http://dx.doi.org/10.1016/j. jff.2010.02.001.

Nielsen PM. 1999. Functionality of protein hydrolysates. In: Food Proteins and Their Applications. Damodaran S and Paraf A, eds. Marcel Dekker, New York, US, pp. 443-472.

Oyaizu M. 1986. Studies on products of browning reaction: antioxidative activities of products of browning reaction prepared from glucosamine. Jpn J Nutr 44, 307-315. http://dx.doi.org/10.5264/ eiyogakuzashi.44.307.

Pfeffer MA and Frohlich ED. 2006. Improvements in clinical outcomes with the use of angiotensin-converting enzyme inhibitors: cross-fertilization between clinical and basic investigation. Am J Physiol-Heart Circ Physiol 291, H2021-H2025. http://dx.doi. org/10.1152/ajpheart.00647.2006.

Qian ZJ, Je JY and Kim SK. 2007. Antihypertensive effect of angiotensin I converting enzyme-inhibitory peptide from hydrolysates of bigeye tuna dark muscle, Thunnus obesus. J Agric Food Chem 55, 8398-8403. http://dx.doi.org/10.1021/jf0710635.

Rajapakse N, Mendis E, Byun HG and Kim SK. 2005. Purification and in vitro antioxidative effects of giant squid muscle peptides on free radical-mediated oxidative systems. J Nutr Biochem 16, 562-569. http://dx.doi.org/10.1016/j.jnutbio.2005.02.005.

Shahidi F. 1994. Proteins from seafood processing discards. In: Seafood Proteins. Sikorski Z, Pan BS and Shahidi F, eds. Chapman and Hall, New York, US, pp. 171-193.

Vyssoulis GP, Karpanou EA, Papavassiliou MV, Belegrinos DA, Giannakopoulou AE and Toutouzas PK. 2001. P-257: side effects of antihypertensive treatment with ACE inhibitors. Am J Hypertens 14(Suppl 1), 114A-115A. http://dx.doi.org/10.1016/S08957061(01)02111-2.

Wu HC, Chen HM and Shiau CY. 2003. Free amino acids and peptides as related to antioxidant properties in protein hydrolysates of mackerel (Scomber austriasicus). Food Res Int 36, 949-957. http:// dx.doi.org/10.1016/S0963-9969(03)00104-2.

Yang B, Yang H, Li J, Li Z and Jiang Y. 2011. Amino acid composition, molecular weight distribution and antioxidant activity of protein hydrolysates of soy sauce lees. Food Chem 124, 551-555. http:// dx.doi.org/10.1016/j.foodchem.2010.06.069.

Zhao XH and Li YY. 2009. An approach to improve ACE-inhibitory activity of casein hydrolysates with plastein reaction catalized by Alcalase. Eur Food Res Technol 229, 795-805. http://dx.doi. org/10.1007/s00217-009-1110-4. 